\title{
Do High-Performance Work Practices Influence Organizational Innovation? Mediating Role of Human Capital
}

\author{
Amna Yousaf ${ }^{l}$, Qasim Ali Nisar ${ }^{2}$, Shahzad Ali ${ }^{3}$, Muhammad Sajjad Hussain ${ }^{4}$, \\ Aamir Zamir Kamboh \\ 1,2,3,5 Department of Management Sciences, The Superior College Lahore, Pakistan \\ ${ }^{4} \mathrm{PhD}$ Candidate, School of Economics, Finance \& Banking, Universiti Utara Malaysia \\ Email: qasim.nasir@ superior.edu.pk
}

\begin{abstract}
Due to globalization and competitive business environment, organizations need to update their information to remain innovative and competitive. Moreover, high-performance work practices (HPWPs) play a vital role that determines organizational success. The current study is performed to scrutinize the effect of high-performance work practices on the organizational innovation with the mediating effect of human capital. Survey questionnaire method was adopted, and data were collected from 202 employees by applying simple random sampling technique. Scales validation has been checked by confirmatory factor analysis (CFA) by using Smart PLS. Moreover, the structure equation modeling technique (SEM) has also been used to test the hypotheses. Findings revealed that there is a positive and significant relationship between high-performance work practices (participation, empowerment, work-life balance, recruitment \& selection) and organizational innovation. Additionally, results also purported that human capital significantly mediates the relationship b/w high-performance work practices (participation, empowerment, work-life balance, recruitment \& selection) and organizational innovation.
\end{abstract}

Keywords: High-Performance Work Practices, Participation, Empowerment, Work-Life Balance, Recruitment \& Selection, Human Capital, Organizational Innovation

\section{Introduction}

The banking sector experienced a lack of organizational innovation that is one of the parameters of enjoying competitive advantages on others. Organizational Innovation (OI) is helpful for creating other opportunities in businesses (Bukhari \& Rahimuddin, 2010). For example, electronic banking, globally the banking system has already moved toward the paperless banking system however in Pakistan, manual banking still exists along with 
electronic banking, but there is a need to move completely towards e-banking (Solangi, 2015). Because by adopting this innovation, it is a much faster way for customers to transact. However, in the banking sector of Pakistan, they pay less attention to technological innovation as it is the need of time (Bukhari \& Rahimuddin, 2010). Even though the growing consideration of organizational innovation, research on high-performance work practices (HPWPs) and organizational outcomes are limited (Jyoti, Chahal, \& Rani, 2017; Shazadi, Nadeem, Nisar, \& Azeem, 2017). Almost scant research is available on organizational innovation in the banking sector of Pakistan. Moreover, prior literature almost ignored the mediating role of human capital.

Secondly, a previous study chooses a small sample size and different sampling technique, but in the present study, the sample size and sampling technique are different. Moreover, lastly, most of the studies on HPWP and organizational outcome were conducted in European countries, and less research is available on Pakistani cultural context. Moreover, mostly the literature is available on the hotel industry and healthcare sector, but there is gap that exists in the banking sector. So, the current study sought to examine the influence of HPWPs on the organizational outcome.

\section{Literature Review}

\section{A. High-Performance Work Practices (HPWPs) and Organizational Innovation (OI)}

According to Damanpour and Evan (1984), Organizational innovations (OI) consist of "changes in the structure and processes of an organization due to implementing new managerial and working concepts and practices, such as the implementation of teamwork in production, supply chain management or quality-management systems”. Nieves and Quintana (2016) conducted research on human resource practices and innovation. Data gathered from 109 firms and the result shown that HR practices enhance innovation performance. Moreover, Beugelsdijk (2008) conducted same research on 988 firms, and the results indicate that human resource practices directly affect the innovation. Earlier researchers pay less attention to organizational innovation as an organizational outcome. Preceding researches available on organizational performance but scant research is available on organizational innovation. Therefore, on the basis of the above arguments following hypotheses are proposed:

$\mathbf{H}_{1}$ a: There is a significant and positive relationship between participation and organizational innovation (OI).

$\mathbf{H}_{1} \mathbf{b}$ : Empowerment is significantly and positively associated with organizational innovation. 
Pakistan Journal of Humanities and Social Sciences, 7(1), 2019

$\mathbf{H}_{1} \mathbf{c}$ : Work-life balance is significantly and positively related to organizational innovation.

$\mathbf{H}_{1} \mathbf{d}$ : There is a significant and positive relationship between recruitment \& selection and organizational innovation.

\section{B. Mediating Role of Human Capital (HC)}

According to Lopez-Cabrales, Pérez-Luño, and Cabrera (2009) researched on HRM practices and human capital. The study shows that there is a positive relationship between HR practices and human capital. Human resource practices enhance HC. Moreover, CabelloMedina, López-Cabrales, and Valle-Cabrera (2011) conducted a research on the effect of HRM and human capital. The study indicates a positive impact of HR practices on human capital. Similarly, Nieves and Quintana (2016) also performed a study on human resource practices and human capital. Data generated from 109 firms of the hotel industry and the result shows that HPWPs influence the human capital. Human capital is positively related to HPWPs. High-performance practices are positively and significantly related to HC.

The previous study is available on high-performance work practices and human capital but they focused on recruitment and selection as a dimension, but another dimension like work-life balance is almost ignored. Further, Nieves and Quintana (2016) examined the role of HPWP on HC and recommended to probe other dimensions of HPWPs in future studies. Therefore, in the light of previous studies and the literature reviewed, the study hypothesized $\mathrm{H}_{2}$ as under:

$\mathbf{H}_{2} \mathbf{a}$ : Employees' participation is significantly and positively associated with human capital.

$\mathbf{H}_{2} \mathbf{b}$ : Employees' empowerment is significantly and positively related to human capital.

$\mathbf{H}_{2} \mathbf{c}$ : Work-life balance is significantly and positively related to human capital.

$\mathbf{H}_{2} \mathbf{d}$ : There is a significant and positive relationship between recruitment and selection and human capital.

Cabello-Medina et al. (2011) demonstrated research on human capital and organizational innovation. Data taken from 85 firms and the result shows a direct and positive relationship between human capital and innovative performance. In addition, one study shows that persons having more cognitive ability are more innovative (Hayton \& Kelley, 2006). Furthermore, Lopez-Cabrales et al. (2009) and Cabello-Medina et al. (2011) purported in their research that HC has a positive impact on innovation. Moreover, Nieves and Quintana (2016) explore a topic related to human resource practice and innovation. Data gathered from a survey of 109 firms, and the result indicates that there is a significant and positive relationship 
between human capital (HC) and innovation. Further, in the context of the banking sector in Pakistan, the interplay of Human capital and the organizational outcome has not been investigated. Consequently, the study explores the organizational outcome of the banking sector as the consequences of human capital in the present study. In the light of the abovementioned discussion, the following hypothesis has been proposed:

H3: $\quad$ There is a significant and positive relationship between human capital (HC) and organizational innovation (OI).

Although some analytical studies have revealed a direct relationship between certain Human Resource Management practices and innovation (Beugelsdijk, 2008; Laursen \& Foss, 2003), one theory underlying investigation on indirect impact rather than direct impact, these HRM practices could influence innovation through influence on some organizational variables. Some researchers argued that human resource practices increase the human capital (HC) and in return, it has a positive impact on innovation (Cabello-Medina et al., 2011; Lopez-Cabrales et al., 2009). The researcher also stated that "knowledge management activities mediate the relationship between HRM practices and innovation" (Chen \& Huang, 2009). According to Nieves and Quintana (2016), T\&D (training and development), R\&S (recruitment and selection), and IT human resource management practices affect the Human capital, which in return gives organizations more ability to innovate.

A prior study showed that human capital as the outcome or result of highperformance work practices, but the mediating role of human capital had not been investigated between high-performance work practices and organizational innovation (OI). The literature about this mediating role was silent to explore the mediating role of $\mathrm{HC}$ on HPWP-OI relationship. Therefore, in the line of prior researcher's suggestions, this study addressed the gap and the following hypothesis has been proposed:

$\mathbf{H}_{\text {a: }} \quad$ Human capital (HC) significantly mediates the relationship between participation and organizational innovation (OI).

$\mathbf{H}_{7 \mathbf{b}}$ Human capital (HC) significantly mediates the relationship between empowerment and organizational innovation (OI).

$\mathbf{H}_{\text {7c: }} \quad$ Human capital (HC) significantly mediates the relationship between work-life balance and organizational innovation (OI).

$\mathbf{H}_{\text {7d: }} \quad$ Human capital (HC) significantly mediates the relationship between recruitment \& selection and organizational innovation (OI). 


\section{Theoretical framework}

Figure 1

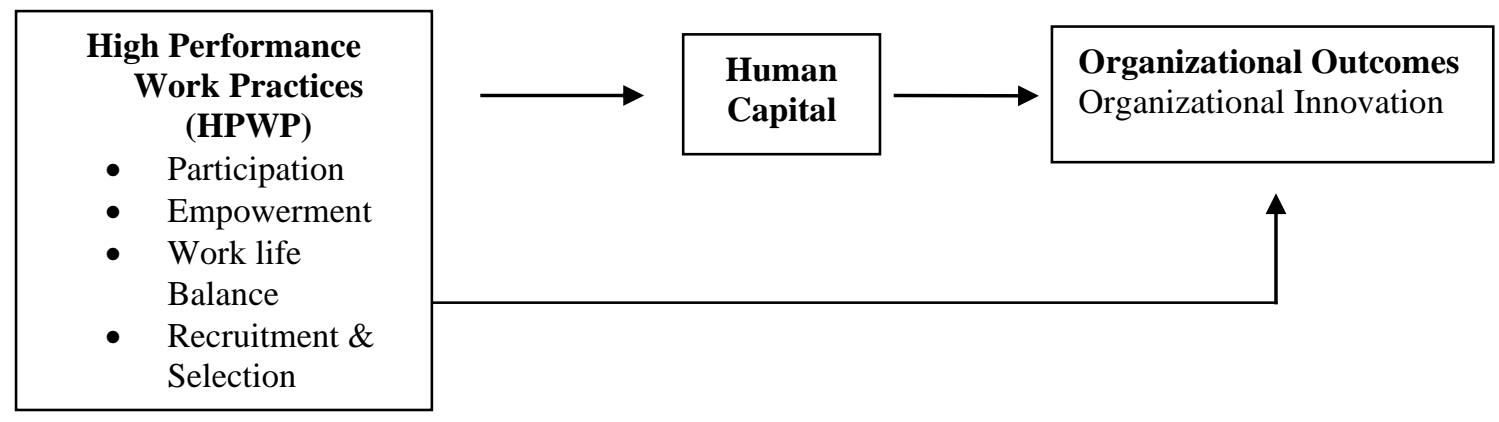

\section{Methodology}

\section{A. Design \& Sample}

The data were gathered from the employee of banks. About 450 questionnaires were distributed among employees, and only 230 questionnaires were returned back, and about 28 questionnaires were excluded due to missing value, and 202 questionnaires were used in data analysis. Demographic profile shows that most of the respondents were male (55.4\%) while the remaining $44.6 \%$ were female. Regarding the age group, 49 percent of the respondents are of the age group of 26 to 45 with 99 participants. There were 85 respondents, representing $42.1 \%$ of the sample. Next the age group of above 56 with 11 respondents, representing 5.4 percent. The smallest group was up to 25 , which represented 3.5 percent or 7 respondents. In terms of qualification, a greater percentage of participants is holding Ph.D. degree 65.3\%, while $26.7 \%$ are holding the Bachelor degree. Moreover, only 7.9 percent of respondents are holding a master's degree. These figures depict that banks are providing more preference to qualified \& professional staff. A more significant number of respondents are mostly permanent having $92.1 \%$, the respondents doing the job on contractual basis represented 3.5 percent and $4.5 \%$ categorized as others. For the current study, more than half of the respondents $(64.9 \%)$ having experience of 5 to 10 years while $23.8 \%$ of respondents have above 10 years of experience. Only $8.9 \%$ respondents are having the length of service of 2 to 5 years while $2.5 \%$ of respondents is having up to 1 year of the length of service.

\section{B. Measures}

All the instruments for this research were adapted from past reliable and valid scales. Five-point Likert scales were adopted to measure the items of survey questionnaire ranking from strongly disagree to strongly agree (1 to 5). For measuring Employee participation, a 
scale of five items is used (Scott, Bishop, \& Chen, 2003). A sample item is "In general how much say, or influence do you have on you perform your job?" This scale is mostly used in past studies with a high coefficient alpha value $(\alpha=0.896)$ for participation in decision making. The scale of employee empowerment consists of six items (Paré \& Tremblay, 2000). The sample item of empowerment is "Employees are involved in decision making about company issues". The scale of Recruitment \& Selection comprises of six items (Collins, 2000). The sample item is "We plan which types of employee skills and abilities will be necessary to achieve the strategies defined by the firm". Work-life balance is measured by 11 items scale of Al Sumaiti (2010). The sample item is "I always think of my family while I am working". A survey item by Youndt and Snell (2004) which comprises of 5 items are adopted to measure Human capital. A sample survey item is "Our employees are highly skilled". The scale of organizational innovation consists of five items (Nasution, Mavondo, Matanda, \& Ndubisi, 2011). The sample survey item is "We constantly introduce new ways of managing our business".

\section{Data Analysis \& Findings}

\section{A. Confirmatory Factor Analysis (CFA)}

Table 1

\begin{tabular}{|c|c|c|c|c|c|}
\hline Construct & Items & Loadings & Alpha & CR & AVE \\
\hline Employee Participation & & & 0.865 & 0.904 & 0.654 \\
\hline & EP1 & 0.829 & & & \\
\hline & EP2 & 0.878 & & & \\
\hline & EP3 & 0.871 & & & \\
\hline & EP4 & 0.743 & & & \\
\hline & EP5 & 0.707 & & & \\
\hline & & & 0.881 & 0.911 & 0.631 \\
\hline & EMP1 & 0.751 & & & \\
\hline & EMP2 & 0.851 & & & \\
\hline & EMP3 & 0.871 & & & \\
\hline & EMP4 & 0.844 & & & \\
\hline & EMP5 & 0.704 & & & \\
\hline & EMP6 & 0.729 & & & \\
\hline & & & 0.913 & 0.927 & 0.536 \\
\hline & WLB1 & 0.61 & & & \\
\hline & WLB2 & 0.751 & & & \\
\hline & WLB3 & 0.781 & & & \\
\hline & WLB4 & 0.746 & & & \\
\hline & WLB5 & 0.701 & & & \\
\hline & WLB6 & 0.738 & & & \\
\hline & WLB7 & 0.727 & & & \\
\hline
\end{tabular}


Pakistan Journal of Humanities and Social Sciences, 7(1), 2019

\begin{tabular}{|c|c|c|c|c|c|}
\hline & WLB8 & 0.771 & & & \\
\hline & WLB9 & 0.755 & & & \\
\hline & WLB10 & 0.775 & & & \\
\hline & WLB11 & 0.68 & & & \\
\hline Recruitment \& Selection & & & 0.903 & 0.929 & 0.691 \\
\hline & HRS1 & 0.857 & & & \\
\hline & HRS2 & 0.899 & & & \\
\hline & HRS3 & 0.908 & & & \\
\hline & HRS4 & 0.893 & & & \\
\hline & HRS5 & 0.844 & & & \\
\hline & HRS6 & 0.519 & & & \\
\hline Organizational Innovation & & & 0.843 & 0.887 & 0.615 \\
\hline & OI1 & 0.659 & & & \\
\hline & OI2 & 0.71 & & & \\
\hline & OI3 & 0.765 & & & \\
\hline & OI4 & 0.883 & & & \\
\hline & OI5 & 0.879 & & & \\
\hline & & & 0.902 & 0.927 & 0.718 \\
\hline & HC1 & 0.816 & & & \\
\hline & HC2 & 0.891 & & & \\
\hline & HC3 & 0.852 & & & \\
\hline & HC4 & 0.807 & & & \\
\hline & HC5 & 0.869 & & & \\
\hline
\end{tabular}

Figure 2

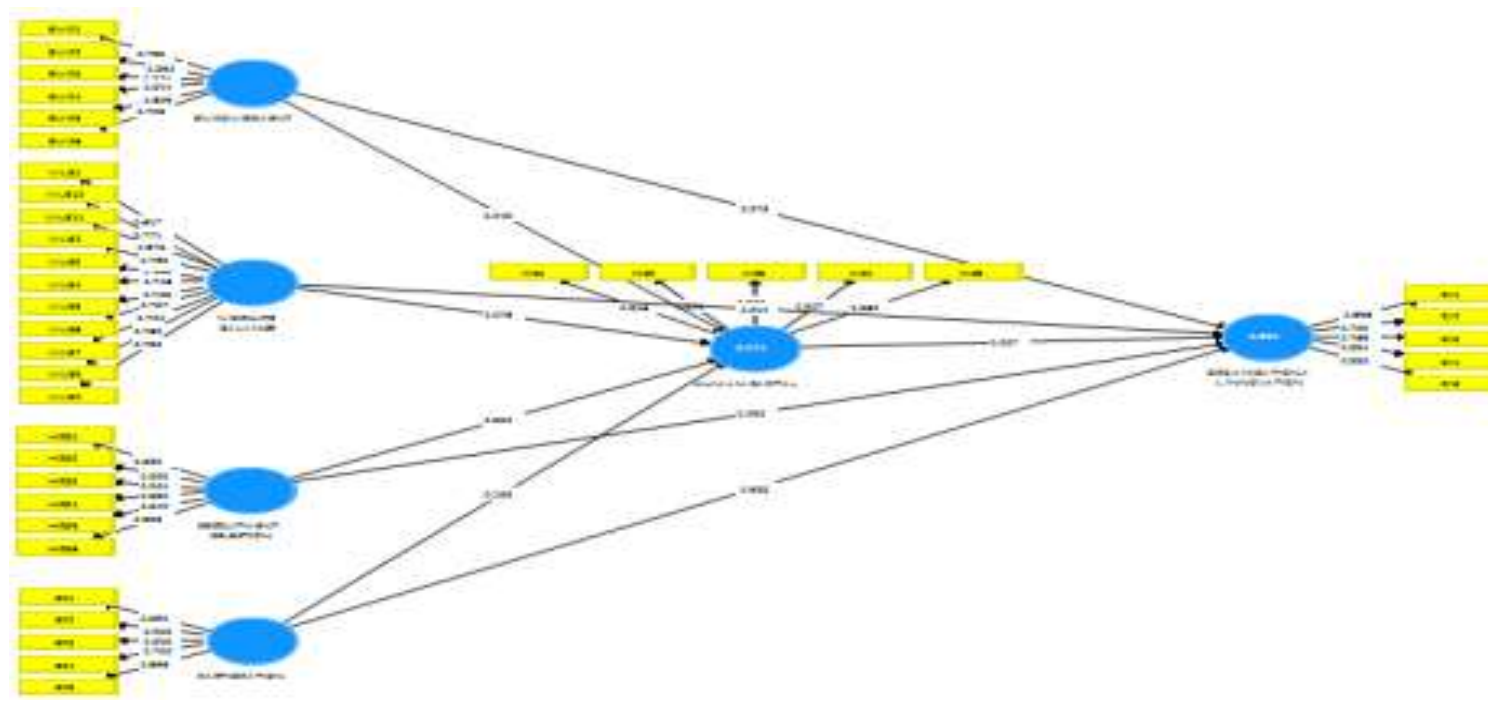

The validity of "measurement scale" is considered as convergent when items loading high (i.e., > 0.50) on their variables (Hair, Ringle, \& Sarstedt, 2011). As shown in Table-1, all the items were in the limit of 0.590 to 0.852 . The AVE value for all variables is above 0.50 , 
and $\mathrm{CR}$ is above 0.8 , representing that "convergent validity" of variables has been established.

\section{B. Discriminant Validity}

Table 2: HTMT-Ratio

\begin{tabular}{|l|l|l|l|l|l|l|}
\hline & EMP & HC & OI & EP & HRS & WLB \\
\hline EMP & & & & & & \\
\hline HC & 0.56 & & & & & \\
\hline OI & 0.49 & 0.59 & & & & \\
\hline EP & 0.45 & 0.63 & 0.88 & & & \\
\hline HRS & 0.47 & 0.67 & 0.77 & 0.74 & & \\
\hline WLB & 0.77 & 0.63 & 0.67 & 0.69 & 0.72 & \\
\hline
\end{tabular}

Table 2 depicts the HTMT ratio that is to access the 'discriminant validity'. Gold et al. (2001) stated that "Heterotrait-Monotrait ratio" should be "less than 0.90 " to assure discriminant validity. According to this criterion, all the values are less than 0.90

\section{Structural Equation Modelling}

Table 3: Main Effects

\begin{tabular}{|l|l|l|l|l|l|l|l|}
\hline Hypothesis & Relationship & $\begin{array}{l}\text { Std. } \\
\text { Beta }\end{array}$ & $\begin{array}{l}\text { Std } \\
\text { error }\end{array}$ & t-Value & Decision & $\mathbf{R}^{\mathbf{2}}$ & $\mathbf{F}^{\mathbf{2}}$ \\
\hline $\mathrm{H}_{\mathrm{a}}$ & EP->OI & 0.553 & 0.071 & 7.741 & Supported & 0.442 & 0.445 \\
\hline $\mathrm{H}_{1 \mathrm{~b}}$ & EMP->OI & 0.075 & 0.065 & 1.155 & Not Supported & & 0.009 \\
\hline $\mathrm{H}_{1 \mathrm{c}}$ & WLB->OI & 0.012 & 0.081 & 0.149 & Not Supported & & 0.000 \\
\hline $\mathrm{H}_{1 \mathrm{~d}}$ & HRS->OI & 0.281 & 0.074 & 3.822 & Supported & & 0.103 \\
\hline $\mathrm{H}_{2 \mathrm{a}}$ & EP->HC & 0.212 & 0.073 & 2.908 & Supported & 0.471 & 0.042 \\
\hline $\mathrm{H}_{2 \mathrm{~b}}$ & EMP->HC & 0.241 & 0.08 & 2.996 & Supported & & 0.057 \\
\hline $\mathrm{H}_{2 \mathrm{c}}$ & WLB->HC & 0.175 & 0.104 & 1.682 & Supported & & 0.030 \\
\hline $\mathrm{H}_{2 \mathrm{~d}}$ & HRS->HC & 0.309 & 0.084 & 3.664 & Supported & & 0.084 \\
\hline $\mathrm{H}_{3}$ & HC->OI & 0.13 & 0.058 & 2.241 & Supported & & 0.034 \\
\hline
\end{tabular}

Hypothesis 1a predicted an effect between employee participation (EP) and organizational innovation (OI). Findings clarified that hypothesis $1 \mathrm{a}$ is supported $(\beta=0.553, \mathrm{t}$ = 7.741). Similarly, hypothesis $1 \mathrm{~b}$ expected an effect of Empowerment on Organizational Innovation. Results depicted $\beta=0.075, \mathrm{t}=1.155$, which is less than the criteria; thus Hypothesis $1 \mathrm{~b}$ is not supported. In Addition, Hypothesis 1c describes the impact of WLB on OI. Findings indicated no impact of Work-life Balance on OI $(\beta=0.012, t=0.149)$, Hypothesis $1 \mathrm{c}$ is also not supported. Furthermore, Hypothesis $1 \mathrm{~d}$ anticipated effects of recruitment and selection on organizational innovation and findings exposed a positive effect 
of HRS on OI $(\beta=0.281, t=3.822)$. Hence, Hypothesis $1 \mathrm{~d}$ is supported. Furthermore, Hypothesis 2a foretold an influence of participation on the human capital of bank employees, and the results determined a significant $\&$ positive effect of participation on human capital ( $\beta$ $=0.212, \mathrm{t}=2.908$ ), again Hypothesis $2 \mathrm{a}$ is supported. Hypothesis $2 \mathrm{~b}$ forecasted the influence of empowerment (EMP) on human capital (HC) of bank employees. Results discovered a significant and positive relationship of EMP on HC $(\beta=0.241, t=2.996)$. Therefore the Hypothesis $2 \mathrm{~b}$ is supported. Hypothesis $2 \mathrm{c}$ foretold a relationship of work-life balance (WLB) on $\mathrm{HC}$ of banks. Results exposed a significant and positive impact of WLB on HC ( $\beta=0.175$, $t=1.682$ ), for that reason Hypothesis $2 \mathrm{c}$ also supported. Moreover, Hypothesis $2 d$ estimated an effect of HRS on HC. Results revealed a significant and positive relationship of HRS on $\mathrm{HC}(\beta=0.309, \mathrm{t}=3.664)$. Consequently, the Hypothesis $2 \mathrm{~d}$ also supported. Moreover, hypothesis 3 foretold the influence of human capital on organizational innovation (OI). Results show the positive and significant relationship between $\mathrm{HC}$ and OI $(\beta=0.13, \mathrm{t}=$ 2.241). Thus it supports hypothesis 3 .

\section{Figure 3}

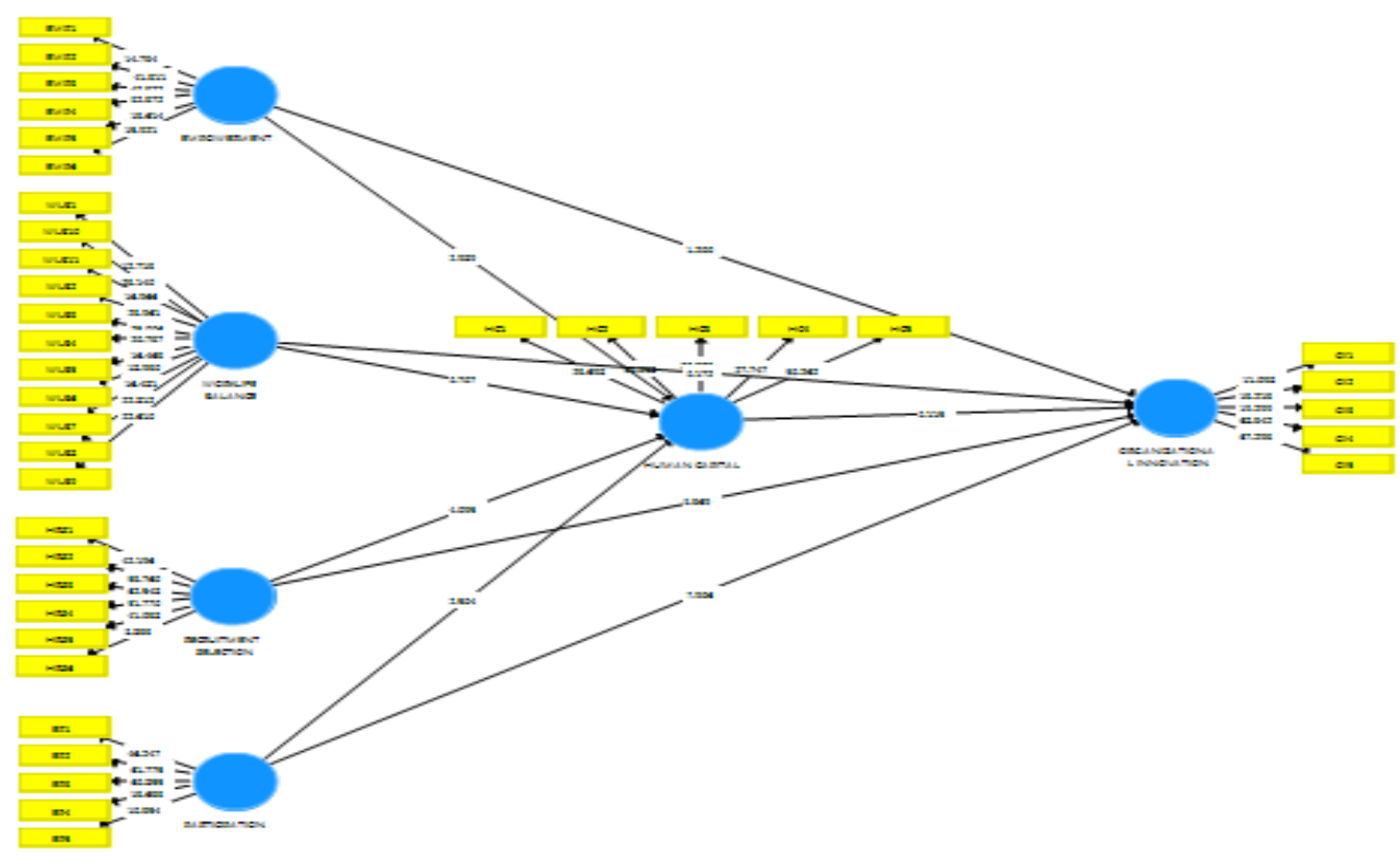




\section{Mediating Role}

Table 4: Indirect Effects

\begin{tabular}{|l|l|l|l|l|l|l|l|}
\hline $\mathbf{H}$ & Relationship & $\begin{array}{l}\text { Std. } \\
\text { Beta }\end{array}$ & $\begin{array}{l}\text { Std. } \\
\text { Error }\end{array}$ & $\begin{array}{l}\text { T } \\
\text { Statistics }\end{array}$ & $\begin{array}{l}\text { Lower } \\
\text { Limit }\end{array}$ & $\begin{array}{l}\text { Upper } \\
\text { Limit }\end{array}$ & Decision \\
\hline $\mathrm{H}_{4 \mathrm{a}}$ & EP-> HC -> OI & 0.342 & 0.054 & 6.331 & 0.027 & 0.03 & Supported \\
\hline $\mathrm{H}_{4 \mathrm{~b}}$ & EMP -> HC -> OI & 0.371 & 0.087 & 4.264 & 0.031 & 0.033 & Supported \\
\hline $\mathrm{H}_{4 \mathrm{c}}$ & WLB -> HC -> OI & 0.305 & 0.081 & 3.765 & 0.016 & 0.019 & Supported \\
\hline $\mathrm{H}_{4 \mathrm{~d}}$ & HRS -> HC -> OI & 0.439 & 0.092 & 4.695 & 0.037 & 0.044 & Supported \\
\hline
\end{tabular}

The "bootstrapping analysis" illustrated above in table\#4 that all the four indirect effects $\beta=0.342, \beta=0.371, \beta=0.305$, and $\beta=0.439$ were significant with $t$-values of 6.331 , 4.264, 3.765, and 4.695 respectively. As indicated by Preacher and Hayes (2008) the indirect effects showed above: [LL $=0.027, \mathrm{UL}=0.03]$, [LL $=0.031, \mathrm{UL}=0.033]$, [LL $=0.016$, UL $=0.019]$, and $[\mathrm{LL}=0.037, \mathrm{UL}=0.044]$ did not include any 0 in between the limits indicating that there is mediation. Thus, it is stated that the "mediating effect" is significant, representing that H4 (a), H4 (b), H4 (c), and H4 (d) were supported.

\section{Discussion \& Conclusion}

The findings of this study show that HPWP plays a vital role in organizational innovation. As hypothesis 1a was developed to evaluate the relationship between participation (EP) and organizational innovation (OI). The results enlightened that there is a positive relationship between EP and OI, so $\mathrm{H}_{1 a}$ is supported. Our findings are congruent with the previous study of Nieves and Quintana (2016). The hypothesis $1 \mathrm{~b}$ was to evaluate the relationship between empowerment and OI. The results elucidated that there is no relationship between EMP and OI, so $\mathrm{H}_{1 \mathrm{~b}}$ is not supported. When an organization gives empowerment to its employees, it will increase their morale, but it does not perform any innovation in the company, so there is no direct relationship (Abdiaziz \& Yassin, 2014). Moreover, hypothesis 1c was to assess the direct effect between work-life balance and organizational innovation. Results revealed that there is no relationship between WLB and OI, so the hypothesis $1 \mathrm{c}$ is not supported. This asserts that a healthy balance between work role and family life will not lead toward OI. Our results are congruent with a prior study (Al Sumaiti, 2010; Mahesar, Chaudhry, Ansari, \& Nisar, 2016). Results showed that there is a positive relationship between recruitment \& selection and organizational innovation and $\mathrm{H}_{1 \mathrm{~d}}$ accepted. According to Jyoti et al. (2017), when an organization adopt good HRS practice and hire highly deserved employee will lead towards the creativeness and innovation. This claims that companies 
prefer to hire qualified employees to stimulate innovation. Additionally, hypothesis 2 a was to estimate the effect of participation and human capital. Findings elucidated a positive effect between $\mathrm{EP}$ and $\mathrm{HC}$ and supported to $\mathrm{H}_{2 \text { a. }}$. This emphasizes that strong participation turns into good HC. This finding is similar to Bantel and Jackson (1989). Results showed a significant relationship between empowerment and human capital and supported $\mathrm{H}_{2 \mathrm{~b}}$. This states that empowerment creates a positive attitude in turns gives good HC. Our results are reliable with other studies (Aliaga, 2001). Hypothesis 2c was to examine the direct relationship between work-life balance and human capital and results supports this hypothesis. A healthy balance may lead to strong HC as discussed in prior studies (Beauregard \& Henry, 2009). Similarly, hypothesis $2 \mathrm{~d}$ showed a relationship between HRS and HC and the findings support hypothesis $2 \mathrm{~d}$. HRS may attract employees with the ability to work in different positions, and they improve the level of $\mathrm{HC}$ in the company. (Becker, 1964).

Likewise, the third hypothesis was to investigate the impact of human capital on organizational innovation, and the consequence supports this hypothesis. According to Nieves and Quintana (2016) summed up that advanced level of HC will capture new ideas and used them more efficiently. Hypothesis $4 \mathrm{a}$ was to investigate the mediating role of $\mathrm{HC}$ between EP and OI. The results support this hypothesis. This declares that employee participation improves the $\mathrm{HC}$ that ultimately enhances the level of innovation. These findings are consistent with the work of Chen and Huang (2009). Similarly, hypothesis $4 \mathrm{~b}$ was developed to check the mediating impact of HC on EMP and OI.

Moreover, the findings showed a significant relationship, and $\mathrm{H}_{4 \mathrm{~b}}$ accepted. Our results are congruent with the results of Lepak and Snell (2002) summed up that by empowering employees, an organization may enhance their level skills and knowledge to develop innovation. Results elucidated a significant mediating relationship of HC between WLB and OI and support hypothesis 4c. Along similar lines, Youndt and Snell (2004) suggest that WLB creates an increase in HC that develop more innovation in the company. Hypothesis $4 \mathrm{~d}$ was established to identify the mediating impact of human capital on HRD and OI and results supports this hypothesis. The result shows that by adopting HRS as HPWPs for the hiring managers enhances the introduction of organizational innovations in the banking sector.

The current study is fulfilling the breach of literature in organizational innovation. The current study will be significant for managers and policymakers because it proposes some practical recommendations and advises how a firm can improve their level of innovation to 
meet the market demands. This study will provide insight into the fundamental role of HPWPs in the organizational outcome. Furthermore, this study will address the issues of banking sector regarding OI and will help the policymakers to plan workable policies. Theoretically, it will add in the literature of innovation so the consequences of this study could append the existing literature of OI.

There are various limitations. Firstly, this research was descriptive research. Secondly, the issue of sample size. This data was obtained from banking employees of the district, Lahore, it can append geographically. All the items were translated into English. It can also be in Urdu. Moreover, it is recommended to perform longitudinal research. Furthermore, this study considers four practices; it is suggested to include some other HPWPs (IT, training \& development) as well. Correspondingly, this research examined only human capital as a mediator; it is recommended to add some other mediators such as learning capability also studied. Similarly, this study was performed on banking employees, but future research could perform in another sector; manufacturing and hotel industry as well. 
Pakistan Journal of Humanities and Social Sciences, 7(1), 2019

\section{References}

Abdiaziz, M., \& Yassin, A. (2014). Corporate innovation and organizational performance: the case of Somalia telecommunication industry. Paper presented at the Proceeding Kuala Lumpur International Business, Economics and Law Conference.

Al Sumaiti, R. S. (2010). The Work Life Balance and Job Satisfaction in Oil and Gas organisations in the UAE context. The British University in Dubai (BUiD).

Aliaga, A. (2001). Human capital, HRD and the knowledge organization. Aliaga AO (Eds.).

Bantel, K. A., \& Jackson, S. E. (1989). Top management and innovations in banking: Does the composition of the top team make a difference? Strategic management journal, 10(S1), 107-124.

Beauregard, T. A., \& Henry, L. C. (2009). Making the link between work-life balance practices and organizational performance. Human Resource Management Review, 19(1), 9-22.

Becker, G. S. (1964). Human Capital: A theoretical and empirical analysis, with special reference to education: National Bureau of Economic Research.

Beugelsdijk, S. (2008). Strategic human resource practices and product innovation. Organization Studies, 29(6), 821-847.

Bukhari, S. A. A., \& Rahimuddin, M. (2010). E-Banking System in Pakistan.

Cabello-Medina, C., López-Cabrales, Á., \& Valle-Cabrera, R. (2011). Leveraging the innovative performance of human capital through HRM and social capital in Spanish firms. The International Journal of Human Resource Management, 22(04), 807-828.

Chen, C.-J., \& Huang, J.-W. (2009). Strategic human resource practices and innovation performance-The mediating role of knowledge management capacity. Journal of Business Research, 62(1), 104-114.

Collins, C. J. (2000). Strategic human resource management and knowledge creation capability: examing the black box between HR and firm performance. University of Maryland, College Park.

Damanpour, F., \& Evan, W. M. (1984). Organizational innovation and performance: the problem of" organizational lag". Administrative science quarterly, 392-409.

Hair, J. F., Ringle, C. M., \& Sarstedt, M. (2011). PLS-SEM: Indeed a silver bullet. Journal of Marketing theory and Practice, 19(2), 139-152.

Hayton, J. C., \& Kelley, D. J. (2006). A competency-based framework for promoting corporate entrepreneurship. Human Resource Management, 45(3), 407-427.

Jyoti, J., Chahal, H., \& Rani, A. (2017). Role of Organizational Learning and Innovation in between High-performance HR Practices and Business Performance: A Study of Telecommunication Sector. Vision, 21(3), 259-273.

Laursen, K., \& Foss, N. J. (2003). New human resource management practices, complementarities and the impact on innovation performance. Cambridge Journal of economics, 27(2), 243-263.

Lepak, D. P., \& Snell, S. A. (2002). Examining the human resource architecture: The relationships among human capital, employment, and human resource configurations. Journal of Management, 28(4), 517-543.

Lopez-Cabrales, A., Pérez-Luño, A., \& Cabrera, R. V. (2009). Knowledge as a mediator between HRM practices and innovative activity. Human Resource Management, 48(4), 485-503.

Mahesar, H. A., Chaudhry, N. I., Ansari, M. A., \& Nisar, Q. A. (2016). Do Islamic HRM Practices Influence Employee Outcomes: Mediating Role of Employee Engagement. International Research Journal of Arts and Humanities, 44(44), 85. 
Nasution, H. N., Mavondo, F. T., Matanda, M. J., \& Ndubisi, N. O. (2011). Entrepreneurship: Its relationship with market orientation and learning orientation and as antecedents to innovation and customer value. Industrial marketing management, 40(3), 336-345.

Nieves, J., \& Quintana, A. (2016). Human resource practices and innovation in the hotel industry: The mediating role of human capital. Tourism and Hospitality Research, 1467358415624137.

Paré, G., \& Tremblay, M. (2000). The measurement and antecedents of turnover intentions among IT professionals. Measurement, 33, 1-38.

Preacher, K. J., \& Hayes, A. F. (2008). Asymptotic and resampling strategies for assessing and comparing indirect effects in multiple mediator models. Behavior research methods, 40(3), 879-891.

Scott, D., Bishop, J. W., \& Chen, X. (2003). An examination of the relationship of employee involvement with job satisfaction, employee cooperation, and intention to quit in US invested enterprise in China. The International Journal of Organizational Analysis, 11(1), 3-19.

Shazadi, A., Nadeem, S., Nisar, Q. A., \& Azeem, M. (2017). Do High Performance Work Practices Influence The Job Outcomes? Mediating Role of Organizational Commitment \& Job Satisfaction: A Longitudinal Study. INTERNATIONAL JOURNAL OF ADVANCED BIOTECHNOLOGY AND RESEARCH, 8(4), 303-314.

Solangi, M. A. (2015). Future of E-Banking in Pakistan. UHasselt.

Youndt, M. A., \& Snell, S. A. (2004). Human resource configurations, intellectual capital, and organizational performance. Journal of managerial issues, 337-360. 